\title{
Changes caused by torrefaction on urban wooden waste
}

\author{
Alterações provocadas pela torrefação sobre \\ resíduos madeireiros de origem urbana \\ Carlos Rogerio Andrade ${ }^{1}$, José Otávio Brito² \\ Ananias Francisco Dias Junior ${ }^{3}$ e Artur Queiroz Lana ${ }^{3}$
}

\begin{abstract}
Resumo
Neste trabalho foram caracterizados resíduos de madeira de origem urbana, antes e depois de submetidos a torrefação. Foram avaliadas cinco composições (tratamentos) de resíduos, compreendendo madeira maciça e painéis reconstituídos, provenientes de uma estação de reciclagem. A torrefação foi realizada em forno elétrico, com atmosfera inerte, saturada em gás nitrogênio, na temperatura de $280^{\circ} \mathrm{C}$ durante 60 minutos. Foram analisadas as propriedades físicas, químicas e energéticas no material in natura e torrificado. Os resultados demostraram que a torrefação aumentou os teores de lignina insolúvel, teor de carbono fixo e poder calorífico superior. Além disso, reduziu os teores de extrativos totais, holocelulose, materiais voláteis, densidade a granel e densidade energética. A torrefação não influenciou nos teores de cinzas, no entanto, mostrou-se eficiente para melhoria da moabilidade dos resíduos. Além disso, o rendimento da torrefação foi afetado tanto pelas características do processo quanto pela composição dos tratamentos avaliados.
\end{abstract}

Palavras-chave: pirolise leve; degradação térmica; biomassa lenhosa; energia da madeira.

\begin{abstract}
This work analyzed torrefied wooden waste from urban origin. Five compositions of residues (treatments) were analyzed, made up by solid wood and panels from a recycling station. Torrefaction was performed in an electric furnace, within an inert atmosphere saturated with nitrogen gas, and a temperature of $280^{\circ} \mathrm{C}$ for 60 minutes. The physical, chemical and energetic properties of raw and torrefied materials were measured. The analysis showed that the torrefaction process led to an increase of acid-insoluble lignin content, fixed carbon content and higher heating value. Furthermore we observed a reduction of extractives, volatile matter, bulk density and energy density. Torrefaction did not affect the ash content, but proved effective to improving the grinding ability of the residues. In addition, the characteristics of the process and samples composition influenced the gravimetric yield of torrefaction.
\end{abstract}

Keywords: mild pyrolysis; thermal degradation; woody biomass; wood energy.

\section{INTRODUCTION}

The use of wooden waste as a feedstock for energy production is a reality in many parts of the world, due to its low cost and its ease of obtaining, where energy is commonly generated. However, urban wood waste like old wooden furniture, construction parts, demolition waste and shipping boxes, usually involves great variation in the possibility of destination, e.g. as a biomass for energy purpose.

In Brazil, the civil construction sector alone and the urban areas generate about 2.79 million tons of wooden waste, most commonly destined to landfill sites for construction works, sanitary landfills, specific landfills (inert landfills), recycling stations and irregular disposal (BRASIL, 2009). The composition of this kind of residue can be considered as complex, since it is formed by a large number of unknown components, the dimensions and moisture content of which generally present wide variations. Besides, it is characterized by low heating value, hygroscopic nature, low density and high volume, which leads to a low energy conversion efficiency, as well as difficulties of collecting, grinding, storing and transporting (CHEN et al, 2015). The optimization of the woody biomass through maximization of its energy features has been studied worldwide through the torrefaction

1Professor at Departament of Forest Sciences. UFG - Universidade Federal de Goiás / REJ - Regional Jataí. 75801-615 - Jataí, GO, Brazil. E-mail: cra.florestal@yahoo.com.br

${ }^{2}$ Senior Professor on Department of Forest Sciences. USP - Universidade de São Paulo / ESALQ - Escola Superior de Agricultura Luiz de Queiroz. Postal Code 9 - 13.400-970 - Piracicaba, SP, Brazil. E-mail: jobrito@usp.br

3Phd Student on Department of Forest Sciences. USP - Universidade de São Paulo / ESALQ - Escola Superior de Agricultura Luiz de Queiroz. Postal Code 9 - 13.400-970 - Piracicaba, SP, Brazil. E-mail: ananiasjr@usp.br, arturqlana@usp.br.

Sci. For., Piracicaba, v. 45, n. 114, p. 275-284, jun. 2017 DOI: dx.doi.org/10.18671/scifor.v45n114.04 
thermal treatment (REPELLIN et al., 2010). This technique known as mild pyrolysis process varying from a few minutes to a few hours, occurs within the temperature range of 200 to $300{ }^{\circ} \mathrm{C}$ without oxygen and with low heating rates (BERGMAN; VERINGA, 2005; CHEN et al., 2013). The thermal degradation process entails changes in the technological properties (PIERRE et al., 2011) e.g. in the loss of water molecules due to the removal of hydroxyl groups present in the chemical structure of the wood (KHAZRAIE SHOULAIFAR et al., 2012). It is a process in which the cell walls are partially degraded resulting in a product whose nature lies between wood and charcoal (PIERRE et al., 2011). Hence, the moisture absorption by torrefied material might be limited from one to six percent (BERGMAN et al., 2005). Others studies indicate a reduction of the time needed for the material ignition (BRIDGEMAN et al., 2008). Moreover, Almeida et al. (2009) reported that if the treatment would have been performed at temperatures above $220^{\circ} \mathrm{C}$, it might result in an increase of dimension stability, incurring in a significant gain for the transport and storage of the material.

Furthermore, improvements were observed in the burning time due to higher fixed carbon content (BERGMAN; KIEL, 2005; BRIDGEMAN et al., 2008; PIERRE et al., 2011), increasing of the heating value (ALMEIDA et al., 2010; BERGMAN et al., 2005), and the energy density (CHEW; DOSHI, 2011). Moreover, torrefaction reduces the smoke emission compared to raw wood (PENTANANUNT et al., 1990), losses of tenacity and fibrous structure, which leads to a reduction of energy expenditure to transform the material in smaller particles (BERGMAN et al., 2005), and the possibility of then using its powdered form in boilers and blast-furnaces (CHEN et al., 2011a). Hence, torrefaction appears as a potential route to improve biomass characteristics aiming at energy use. There is, however, a lack of studies on the use of torrefaction for improving the urban wood waste characteristics. Thereupon, this study aimed to analyze the torrefaction effect on the technological characteristics of different compositions of solid wood waste and waste of wooden panels, collected from an existing recycling plant in Piracicaba County - São Paulo, Brazil.

\section{MATERIAL AND METHODS}

\section{Material}

A recycling plant located in Piracicaba County in the state of Sao Paulo, Brazil, donated the urban wood waste. The waste sampling procedure followed the descriptions in the standard NBR 10007 (ABNT, 2004), which at the time of collection, were separated into solid wooden waste and residues of reconstituted wood panels. 240 samples of solid wood residues and 240 samples of panel residues were collected. The samples were stored in plastic bags and sent to the laboratory for further identification and analysis. Each combination of materials was analyzed in chips in the natural condition and torrefied, as shown in Table 1. The chips were sieved in $31.5 \mathrm{~mm}$ aperture.

Table 1. Composition of treatments.

Tabela 1. Composição dos tratamentos.

\begin{tabular}{ll}
\hline Treatment & Composition \\
\hline T1 & $100 \%$ Solid wood $+0 \%$ Panels \\
T2 & $75 \%$ Solid wood $+25 \%$ Panels \\
T3 & $50 \%$ Solid wood $+50 \%$ Panels \\
T4 & $25 \%$ Solid wood $+75 \%$ Panels \\
T5 & $0 \%$ Solid wood $+100 \%$ Panels \\
\hline
\end{tabular}

\section{Torrefaction}

The torrefactions were carried out in a brand Fanem model 320-Digital kiln, equipped with a heating system set up by an electrical resistance and an internal forced airflow and volume of 450 liters (Figure 1). The samples, absolutely dried, were inserted into the torrefaction reactor, with an access door, holes for the insertion of thermocouples for temperature control, gas evacuation along the process and introduction of nitrogen inside the torrefaction reactor to keep an inert atmosphere. The nitrogen injection began at $180^{\circ} \mathrm{C}$, and remained until the end of the process. The nitrogen flow rate was $30 \mathrm{ml} \mathrm{min}^{-1}$. The furnace was initially at room temperature $\left( \pm 30^{\circ} \mathrm{C}\right)$ and the torrefaction temperature, of $280{ }^{\circ} \mathrm{C}\left( \pm 5^{\circ} \mathrm{C}\right)$, was held for 60 minutes. The heating rate was $1.5^{\circ} \mathrm{C} \cdot \mathrm{min}^{-1}$ and the total time was 3 hours 13 minutes. 


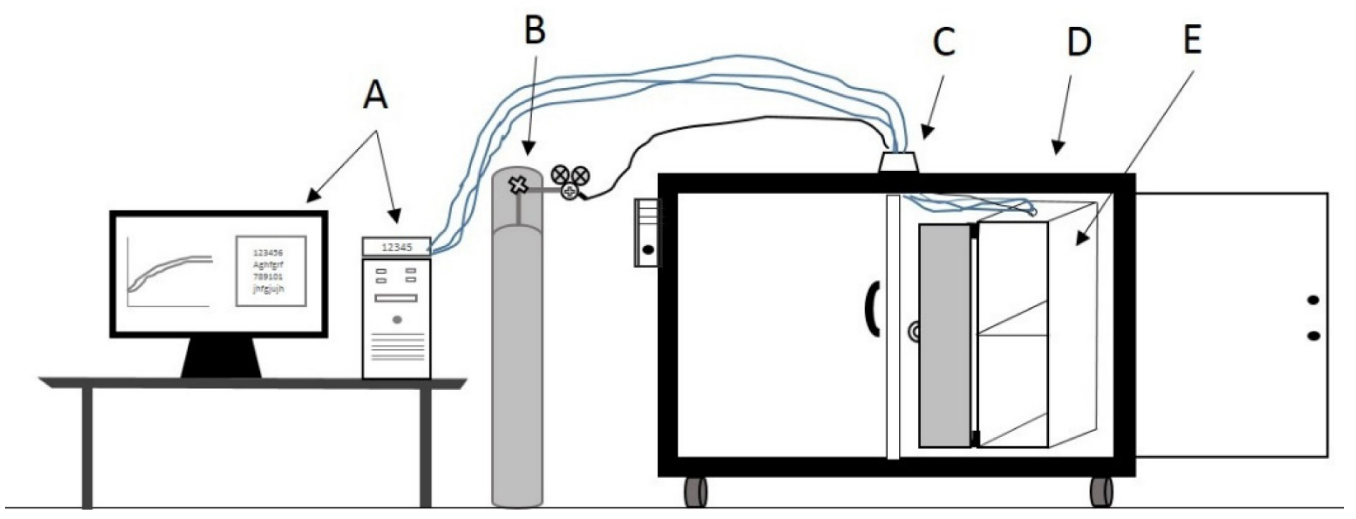

Figure 1. Torrefaction system. A: set of data-logger; B: nitrogen cylinder; C: Holes for nitrogen injection, thermocouple insertion and gases output; D: Electric kiln; E: torrefaction reactor.

Figura 1. Sistema de torrefação: A: conjunto de aquisição de dados; B: cilindro de nitrogênio; C: estufa elétrica; D: orifícios para entrada de nitrogênio, termopares e saída de gases; E: reator de torrefação.

\section{Analysis}

The treatments were done according to the following assays:

- The extractives content was determined in accordance to standard TAPPI T-12 05-75 (TAPPI, 1975); lignin content was defined following the standard TAPPI 222 05-74, (TAPPI, 1974).

- The immediate analysis was done to determine the volatile matter content, the ash content and the fixed carbon content according to NBR 8112 (ABNT, 1986).

- The bulk density was determined according to NBR 6922 (ABNT, 1981) .

- The higher heating value was determined according to NBR 8633 (ABNT, 1984).

- Energy density was calculated by multiplying the higher heating value by the respective bulk density values. Grinding of the chips was processed in a Jokro-Muhle centrifugal grinder, based on the methodology of the norm MERK BLATT-V/105-VZIPC (Verein der Zellstoff und Papier Chemiker und Ingenieure). The grain size classification of the raw and torrefied chips were performed using a set of sieves with a particle size mesh of $31.5 ; 16.0 ; 8.0 ; 4.0$ and $<4.0 \mathrm{~mm}$ of aperture.

- The gravimetric yield of torrefaction was obtained using the relationship between the amount of material after the treatment and prior treatment, according to Equation (1):

$$
\text { Gravimetric yield }(\%)=\frac{\text { Torrefied mass }(\mathrm{g})}{\text { Original mass }(\mathrm{g})} \times 100
$$

\section{Data analysis}

The data were subjected to the Analysis of Variance (ANOVA) using a Completely Randomized Design (CRD) with five replicates per treatment. When necessary, we applied the Tukey test for multiple comparisons of means. All analysis were performed using the software Minitab16.1 ${ }^{\circledR}$ and the "Action” supplement of Microsoft Excel, all at 95 percent of confidence interval.

\section{RESULTS AND DISCUSSION}

The results for the different types of residues sampled, percentages in dry mass, and their moisture contents are listed in Table 2.

Table 2. Mean moisture content of the sampled wastes.

Tabela 2. Teor de umidade médio dos resíduos sólidos amostrados.

\begin{tabular}{lccc}
\hline Waste & N & MS (g) & U (\%) \\
\hline Solid wood & 240 & $68.84[56]$ & $12,26(34,07)$ \\
Plywood panel & 92 & $28.54[23]$ & $12,73(34,32)$ \\
Chipboard panel & 23 & $5.32[4]$ & $13,93(31,16)$ \\
MDF & 76 & $12.48[10]$ & $15,00(28,86)$ \\
OSB & 20 & $3.98[3]$ & $11,01(40,01)$ \\
Hardboards & 29 & $4.52[4]$ & $10,24(42,85)$ \\
\hline
\end{tabular}

$\mathrm{N}$ : number of samples. MS: dry mass. U: moisture. Values among [ represent the percentage of participation in dry mass of each type of waste in relation to the total collected. Values between () are the coefficients of variation of the analyzed residues. 
Analyzing Table 2 it can be noticed that, considering the sample universe, the largest participation was for solid wood residues, with $56 \%$. Within the group of panels, the largest numbers of samples were of plywood residues, representing $23 \%$ of the total dry mass collected, followed by residues of MDF, particleboard, and OSB with 10\%, 23\%, 4\% 4\% and 3\% respectively.

In relation to the moisture content, the highest value was found for MDF residues, with $15 \%$ moisture content, and the lowest value was for $10.24 \%$ in hardboards. It is important to note that the moisture content of the residues is close to the average equilibrium humidity of the collection municipality, which is $12.9 \%$ (JANKOWSKY; GALINA, 2013), which is satisfactory from the energy point of view, because it would require no previous drying of the material.

\section{Chemical properties}

The category of panels to which the proposed treatments refer, is of a sample composed of all types of panels that were found in the sampled residues, respecting the participation in terms of percentage of dry mass of each type of panel.

Table 3 shows the results for extractives, acid-insoluble lignin and holocelulose.

Table 3. Chemical analysis.

Tabela 3. Análise química.

\begin{tabular}{|c|c|c|c|c|}
\hline \multirow{2}{*}{$\mathbf{T}$} & \multicolumn{2}{|c|}{ Extractives (\%) } & \multicolumn{2}{|c|}{ Acid-insoluble Lignin (\%) } \\
\hline & Raw & Torrefied & Raw & Torrefied \\
\hline T1 & $21.37^{\mathrm{aA}}$ & $10.8^{\mathrm{aB}}{ }_{(15.99)}$ & $31.46^{\mathrm{aB}}{ }_{(3.79)}$ & $55.22^{\mathrm{dA}}{ }_{(1.09)}$ \\
\hline T2 & $14.633^{\mathrm{bA}}$ & $9.43 \mathrm{aB}_{(2.78)}$ & $31.00 \mathrm{aB}$ & $55.71 \mathrm{dA}$ \\
\hline T3 & $14.86^{\mathrm{bA}}$ & $9.40 \mathrm{aB}$ & $30.06{ }^{\text {ав }}{ }_{(4.67)}$ & $61.53^{\mathrm{CA}}(1.16)$ \\
\hline T4 & $13.99^{\mathrm{bA}}$ & $9.65_{(7.27)}^{\mathrm{aB}}$ & $28.08^{\mathrm{bB}}{ }_{(2.88)}$ & $72.11^{\mathrm{bA}}(0.67)$ \\
\hline T5 & $14.42^{\mathrm{bA}}{ }_{(2.09)}$ & $9.23{ }^{\mathrm{aB}}{ }_{(8.56)}$ & $27.26{ }^{\mathrm{bB}}{ }_{(4.40)}$ & $84.28{ }^{\mathrm{aA}}{ }_{(0.77)}$ \\
\hline
\end{tabular}

T: treatments. Values followed by the same letter are equal to each other $(p>0.05)$. Lowercase letters compare values between columns for each characteristic separately, and uppercase compare values between lines. Values in parentheses correspond to the coefficient of variation.

According to Pierre et al. (2011), the reduction of extractives content is due to an increase of the thermal degradation of compounds they contain, mainly for temperatures equal or higher to 240 ${ }^{\circ} \mathrm{C}$ and a mass loss exceeding $6 \%$. The effect of the torrefaction process on the extractives content was more effective for the treatment $\mathrm{T} 1$, which decreases from $21.37 \%$ to $10.8 \%$, corresponding to a reduction of $49.5 \%$. For other treatments, whose compositions contained added panels; the mean waste reduction was $34.8 \%$.

T1 exhibited the highest content of extractives, which may be due to a sum of various tree species with unknown chemical characteristics present in the sample. The composition of T2, T3 T4 and T5 included panels of wood waste made exclusively with wood of Pinus spp. and Eucalyptus spp., which may explain their lower content level. In addition, the solvents used for the extraction may have removed not only the wood extractive, but also some kind of weird component adhered to the waste, such as paints, varnishes and glues.

As for lignin content, torrefaction raised it in all the treatments and $\mathrm{T} 5$ had the highest increase of $209 \%$. Lignin is described by Chen and Kuo (2011) as being relatively insensitive to the thermal degradation during the torrefaction. According to Esteves et al. (2008), this increase must be the consequence of the degradation reactions of hemicellulose and cellulose. The report made by the previous authors corroborates the study of Prins et al. (2006), in which the authors describe the greater decomposition of hemicellulose at temperatures ranging from 225 to $325{ }^{\circ} \mathrm{C}$; of cellulose from 305 to $375{ }^{\circ} \mathrm{C}$ and of lignin gradually all over the temperature ranging from 250 to $500{ }^{\circ} \mathrm{C}$.

\section{Immediate analysis}

Table 4 includes the results of volatile matter, ash and fixed carbon contents.

Table 4 highlights a significant reduction of the volatile matter content in all torrefied treatments. T5 showed the highest reduction of $48 \%$ between raw and torrefied material. The observation of other treatments denote that the effect of torrefaction on the volatiles was more pronounced for the samples containing a higher proportion of panels such as T5, T4 and T3, respectively. Volatile matters are mainly constituted of condensable liquids such as $\mathrm{H}_{2} \mathrm{O}$, organics, lipids and a fraction 
of non-condensable gases, mainly $\mathrm{CO}$ and $\mathrm{CO}_{2}$ (CHEN et al., 2011b). In addition, torrefaction may also allow the removal of gaseous nitrogen compounds such as HNCO, HCN throughout the combustion phase; and such as $\mathrm{HCN}, \mathrm{NH}_{3}$ and $\mathrm{NOx}$ compounds during the pyrolysis phase. These compounds may come from varnishes and resins such as urea formaldehyde and melamine formaldehyde, common in wooden waste panels (DEBAL et al., 2014; GIRODS et al., 2008). The release of these volatiles during torrefaction is intrinsic to the process, according to Gucho et al. (2015), Lee et al. (2012) and as reported in van der Stelt et al. (2011): they may contain about 10\% of the energy of the biomass.

Table 4. Immediate analysis.

Tabela 4. Análise imediata.

\begin{tabular}{|c|c|c|c|c|c|c|}
\hline \multirow{2}{*}{$\mathbf{T}$} & \multicolumn{2}{|c|}{ Volatile matter (\%) } & \multicolumn{2}{|c|}{ Ash (\%) } & \multicolumn{2}{|c|}{ Fixed carbon (\%) } \\
\hline & Raw & Torrefied & Raw & Torrefied & Raw & Torrefied \\
\hline T1 & $81.82^{\mathrm{cA}}{ }_{(0.88)}$ & $66.85^{\mathrm{aB}}{ }_{(0.44)}$ & $1.17^{\mathrm{CA}}{ }_{(11.74)}$ & $1.1^{\mathrm{dA}}{ }_{(10.63)}$ & $17.00^{a B}$ & $32.04^{\mathrm{dA}}{ }_{(0.86)}$ \\
\hline T2 & $85.28 \mathrm{bA}$ & $65.26{ }^{a b B}$ & $1.12^{\mathrm{cA}}$ & $1.29 \mathrm{cdA}_{(5.30)}$ & $13.59 \mathrm{bB}$ & $33.43^{\mathrm{cdA}}{ }_{(1.56)}^{(000)}$ \\
\hline T3 & $90.43^{\mathrm{aA}}$ & $62.15^{\mathrm{bB}}$ & $1.97 \mathrm{abA}_{(3.61)}$ & $1.39 \mathrm{cB}$ & $7.59 \mathrm{cB}$ & $36.45^{\mathrm{cA}}$ \\
\hline T4 & $89.17^{\mathrm{aA}}{ }_{(0.87)}$ & $56.24^{\mathrm{cB}}{ }_{(2.43)}$ & $1.93 \mathrm{bB}$ & $2.13 \mathrm{bA}^{\mathrm{b} .47)}$ & 8.89 св & $41.62 \mathrm{bA}$ \\
\hline T5 & 89.20 aA & $46.37 \mathrm{~dB}$ & $2.18 \mathrm{aB}$ & $3.01 \mathrm{aA}(4.00)$ & $8.61^{\mathrm{cB}}{ }_{(20.22)}$ & $50.60{ }^{a A}$ \\
\hline
\end{tabular}

T: treatments. Values followed by the same letter are equal to each other $(p>0.05)$. Lowercase letters compare values between columns for each characteristic separately, and uppercase compare values between lines. Values in parentheses correspond to the coefficient of variation.

Regarding ash content, torrefaction did not show a tendency of increasing or decreasing. It is nevertheless an essential property in the urban wood waste use. The higher its content, either in the raw or in torrefied wastes, the greater the dulling of the cutting tools for crushing and grinding such materials and the lower its higher heating value. An increase of ash resulting from the combustion may also occur (KROOK et al., 2004), leading to more frequent cleaning of furnaces and boilers, as well as, according to Debal et al. (2014), of problems of foulness and clogging.

The fixed carbon content showed differences comparing raw materials and torrefied ones. In this case a general increase for all treatments and T5 presented the greatest increase of $487 \%$ occurred. Indeed, the torrefaction process increases the fixed carbon content, as noted by Bergman and Kiel (2005). This might mean a longer burning time of torrefied materials in comparison with lower fixed carbon content materials (BRIDGEMAN et al., 2008).

\section{Physical and energetic properties}

Table 5 shows the results of bulk density, higher heating value and energy density of treatments.

Table 5. Mean values of bulk density (BD), higher heating value (HHV) and energy density (ED).

Tabela 5. Valores médios de densidade a granel, poder calorífico superior e densidade energética.

\begin{tabular}{|c|c|c|c|c|c|c|}
\hline \multirow{2}{*}{$\mathbf{T}$} & \multicolumn{2}{|c|}{ BD $\left(\mathrm{kg} \mathrm{m}^{-3}\right)$} & \multicolumn{2}{|c|}{ HHV $\left(\mathrm{KJ} \mathrm{kg}^{-1}\right)$} & \multicolumn{2}{|c|}{ ED $\left(\mathrm{KJ} \mathrm{m}^{-3}\right)$} \\
\hline & Raw & Torrefied & Raw & Torrefied & Raw & Torrefied \\
\hline T1 & $\begin{array}{c}233.5^{\mathrm{aA}} \\
(1.01)\end{array}$ & $\begin{array}{c}184.4{ }^{\mathrm{aB}} \\
(1.25)\end{array}$ & $\begin{array}{c}19182.2 \mathrm{abB} \\
(4.74)\end{array}$ & $\begin{array}{c}22453.8^{\mathrm{bA}} \\
(0.62)\end{array}$ & $\begin{array}{c}4480349.0^{\mathrm{aA}} \\
(4.99)\end{array}$ & $\begin{array}{c}4142366.0 \mathrm{aB} \\
(1.34)\end{array}$ \\
\hline T2 & $\begin{array}{c}221.8^{\mathrm{bA}} \\
(1.98)\end{array}$ & $\begin{array}{c}158.0^{\mathrm{bB}} \\
(0.43)\end{array}$ & $\begin{array}{c}19554.8^{\mathrm{aB}} \\
(0.30)\end{array}$ & $\begin{array}{c}22444.6{ }^{\mathrm{bA}} \\
(0.33)\end{array}$ & $\begin{array}{c}4337683.0^{\mathrm{aA}} \\
(1.85)\end{array}$ & $\begin{array}{c}3548070.0^{\mathrm{bB}} \\
(0.38)\end{array}$ \\
\hline T3 & $\begin{array}{l}201.3 \text { cA } \\
(2.96)\end{array}$ & $\begin{array}{c}146.9 \mathrm{cB} \\
(1.28)\end{array}$ & $\begin{array}{c}19100.1 \mathrm{abB} \\
(0.32)\end{array}$ & $\begin{array}{c}22705.0^{\mathrm{bA}} \\
(1.26)\end{array}$ & $\begin{array}{c}3846119.0 \mathrm{bA} \\
(2.93)\end{array}$ & $\begin{array}{c}3335663.0 \mathrm{CB} \\
(1.83)\end{array}$ \\
\hline T4 & $\begin{array}{c}189.4^{\mathrm{dA}} \\
(5.90)\end{array}$ & $\begin{array}{c}128.6^{\mathrm{dB}} \\
(1.19)\end{array}$ & $\begin{array}{c}19153.7 \text { abB } \\
(0.35) \\
\end{array}$ & $\begin{array}{c}23492.9 \text { aA } \\
(0.74)\end{array}$ & $\begin{array}{c}3627427.0 \mathrm{cA} \\
(5.67)\end{array}$ & $\begin{array}{c}3021514.0 \mathrm{~dB} \\
(1.18)\end{array}$ \\
\hline T5 & $\begin{array}{c}187.2 \mathrm{dA} \\
(1.28)\end{array}$ & $\begin{array}{c}109.7^{\mathrm{eB}} \\
(1.84)\end{array}$ & $\begin{array}{c}18708.3^{\mathrm{bB}} \\
(0.29)\end{array}$ & $\begin{array}{c}23841.3^{\text {aA }} \\
(1.13)\end{array}$ & $\begin{array}{c}3502979.0^{\mathrm{CA}} \\
(1.50)\end{array}$ & $\begin{array}{c}2615843.0 \mathrm{eB} \\
(2.35)\end{array}$ \\
\hline
\end{tabular}

T: Treatments. Values followed by the same letter are equal to each other $(\mathrm{p}>0.05)$. Lowercase letters compare values between columns for each characteristic separately, and uppercase compare values between lines. Values in parentheses correspond to the coefficient of variation coefficient.

Table 5 shows an effect of torrefaction on the bulk density being more pronounced for treatments with higher percentages of waste panels in their composition. The greatest density difference between the raw and the torrefied material was for T5 which had a $41 \%$ reduction. This assay presented a trend: the greater the percentage of panels the greater the mass loss and the lower the bulk density.

These decreases of the bulk density values may be due to the different mass loss observed among 
the different treatments, by differences of material compositions of each treatment as well as the duration time and temperature used in the assay. The trends are similar to the results of Almeida et al. (2009), who worked with different woods with different temperature conditions, and verified a loss of mass greater than $25 \%$ at a temperature of $280{ }^{\circ} \mathrm{C}$.

The torrefied material presented a considerable increase of the higher heating values comparing to the raw ones. T2 and T5 presented an increase of $14.7 \%$ and $27.4 \%$, respectively. According to Almeida et al. (2010), this fact induced by torrefaction indicates an increase in the quality of the product compared to the non torrefied biomass. The results are similar of those obtained by Bergman et al. (2005); W. H. Chen et al. (2011c); Phanphanich and Mani (2011).

On the other hand, energy density, calculated from the bulk density and the higher heating value, showed a significant reduction in its values when comparing raw and torrefied materials. In this case, the reduction of this property lies between $7.5 \%$ and $25.3 \%$ for the samples of T1 and T5, respectively.

It is worth noting that the reduction of the energy density values is in no way desirable because it implies in energy losses. Viguié et al. (2013) have reported a maximum weight loss of $30 \%$ during the torrefaction process to be acceptable. However, despite losses below this limit and an increment of the higher heating values, the energy density of the torrefied material might not be satisfactory enough, when compared to the raw material. If that happens, it is necessary to adjust the process parameters as temperature, residence time, and type of biomass, as highlighted by Almeida et al. (2010) and Neupane et al. (2015).

However, energy density is not the sole parameter to take into account to determine the outcome of torrefaction. The quality of the material depends on the intended application, and may also be expressed in terms of qualitative improvement of the characteristics of the biomass. For instance, a greater homogeneity, an improved resistance to biological degradation in storage and lower moisture content can be significantly advantagious.

Figure 2 shows the results of the grinding test performed.

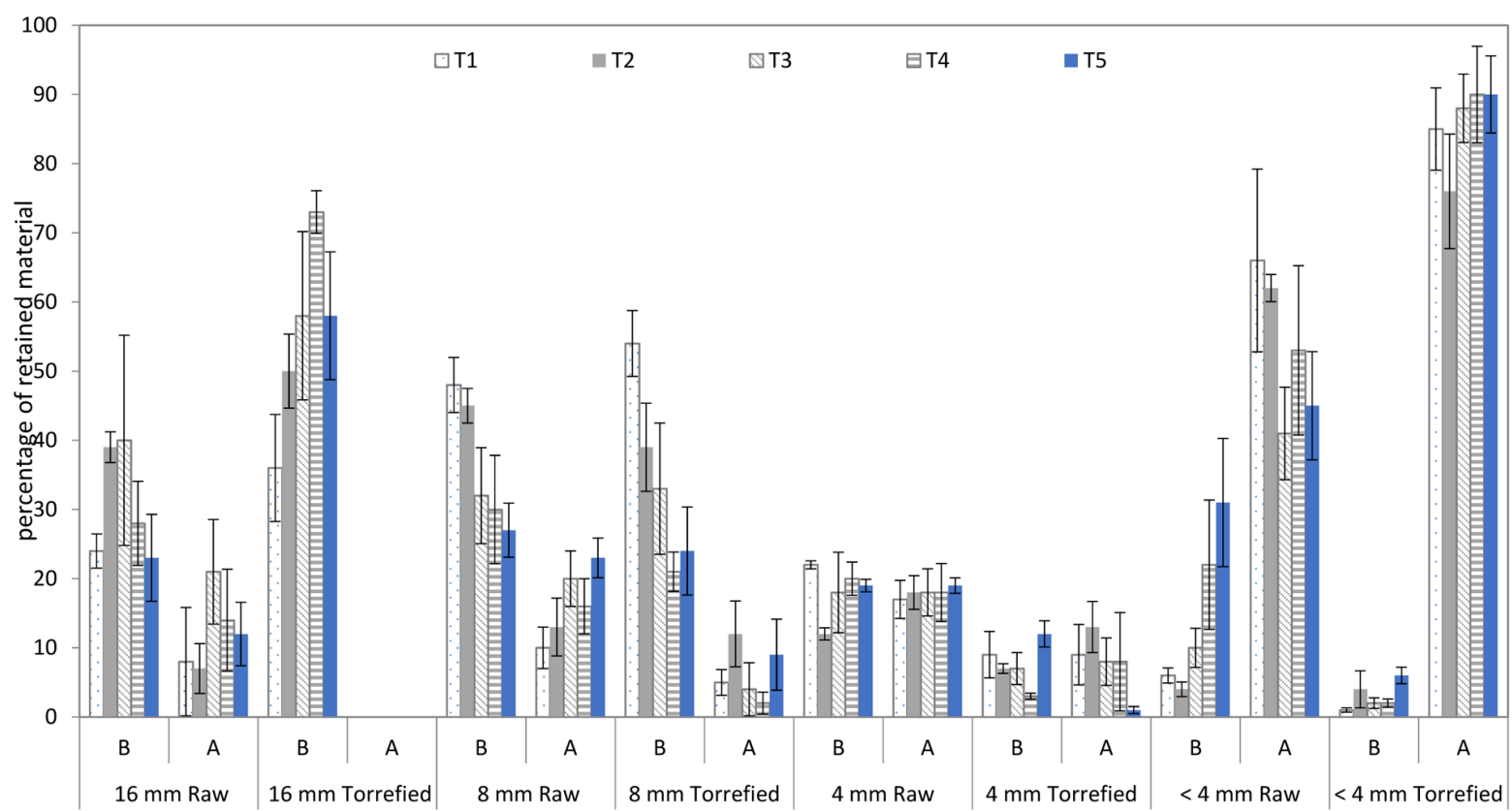

Figure 2. Size distribution of the particles in different grain sizes before (B) and after (A) grinding (dry weight percentage retained in the sieve).

Figura 2. Distribuição do tamanho das partículas em diferentes granulometrias antes (B) e depois da moagem (A) (\% de massa seca retida na peneira).

Figure 2 denotes the torrefaction effect on the grinding resistance on the raw particles and torrefied waste. The largest particles, passed through a $16 \mathrm{~mm}$ mesh sieve, had a $0 \%$ retention of material after grinding (A), was which means a 100\% reduction of the particle size. The $8 \mathrm{~mm}$ sieve evidenced this increase in friability of torrefied material, when compared to the raw material, and had a much lower retention after grinding (A) in all treatments. 
As for particles smaller than $4 \mathrm{~mm}$, torrefied material presented an increase of particles after grinding (A) compared with raw material in the same treatment (A). The presumable further fragmentation of particles sieved in 16,8 and $4 \mathrm{~mm}$, accumulated fine particles on the bottom of the sieves.

The grinding of the torrefied biomass had the practical effect reported by Bergman et al. (2005): the authors observed reductions of 50 to $85 \%$ of electricity consumption during the grinding process of torrefied when compared to the raw wood waste. Phanphanich and Mani (2011) also reported a possible significant reduction of the grinding energy expenditure when using torrefaction. Bridgeman et al. (2010) reported that, in addition to reducing energy cost, the resulting particulate of the grinding would present better flowing ability properties.

Figure 3 shows the average values of the gravimetric yields.

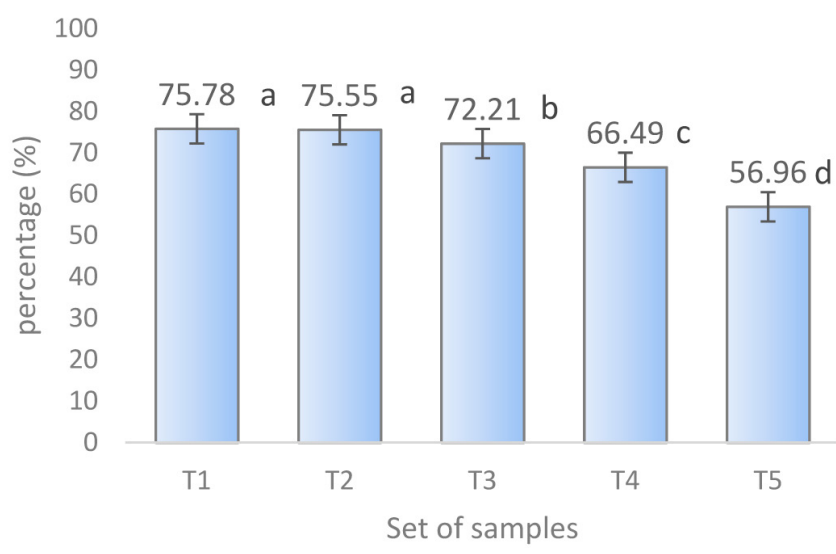

Figure 3. Gravimetric yield of torrefaction in different treatments. Values followed by the same letter are equal to each other $(p>0.05)$.

Figura 3. Rendimento gravimétrico do material torrificado para os diferentes conjuntos de amostras. Valores seguidos pela mesma letra são considerados iguais entre si $(p>0.05)$.

Figure 3 shows a distinct reduction of torrefaction efficiency, according to the composition of the treatments with higher levels of waste panels. The difference between the T1 to T5 gravimetric yields was about $18.82 \%$, the highest value being for $\mathrm{T} 1$. This explains the significant influence of torrefaction on the treatments with higher waste panels' content. This result is of great importance for the proper planning and adjustment of process parameters in order to maximize yields and the final quality of torrefied biomass.

Viguié et al. (2013) describes a typical gravimetric yield for torrefaction of solid material (dry basis) around 70\%. By using this value as a reference, T1, T2 and T3 lie within the pattern described by the author. On the other hand, the gravimetric yields of less than $70 \%$ of T4 and T5 can be explained by Cavagnol et al. (2015). Indeed, although the torrefaction process is endothermic, some exothermic reactions may occur at temperatures above $250{ }^{\circ} \mathrm{C}$, producing excessive heat, creating hot spots in the reactor, changing directly the behavior of certain particles. Yet according to the authors, the temperature in the inner core of the chips will have a direct impact on the mass income of torrefaction.

In general, there were many differences observed between the five treatments. Regardless of the studied features, it is crucial to know the qualitative characteristics of the biomass to be torrefied as well as the temperature and the residence time of process. Only thus can torrefaction be conducted properly as an alternative to the treatment of urban wood waste, targeting its use as energy source.

\section{CONCLUSIONS}

Torrefaction has made significant and positive increases in the acid-insoluble lignin content, fixed carbon and higher heating value. It has caused a significant reduction in the levels of extractives, volatile matter, bulk density and energy density. While torrefaction has not affected the ash content, it had effectively improved the grinding ability of torrefied waste compared to respective raw materials. The blends of biomasses adopted affected the conversion process efficiency. 
Andrade et al. - Changes caused by torrefaction on urban wooden waste

\section{ACKNOWLEDGEMENTS}

The authors thank to the College of Agriculture "Luiz de Queiroz" - ESALQ, of University of Sao Paulo - USP, Brazil, for support in this research.

\section{REFERENCES}

ALMEIDA, G.; BRITO, J. O.; PERRÉ, P. Changes in wood-water relationship due to heat treatment assessed on micro-samples of three Eucalyptus species. Holzforschung, Berlin, v. 63, n. 1, p. 80-88, 2009.

ALMEIDA, G.; BRITO, J. O.; PERRÉ, P. Alterations in energy properties of eucalyptus wood and bark subjected to torrefaction: The potential of mass loss as a synthetic indicator. Bioresource Technology, v. 101, n. 24, p. 9778-9784, 2010.

ABNT - ASSOCIAÇÃO BRASILEIRA DE NORMAS TÉCNICAS. NBR 10007: amostragem de resíduos sólidos. Rio de Janeiro, 2004. 21 p.

ABNT - ASSOCIAÇÃO BRASILEIRA DE NORMAS TÉCNICAS. NBR 8112: análise química imediata do carvão vegetal. Rio de Janeiro, 1986, 5 p.

ABNT - ASSOCIAÇÃO BRASILEIRA DE NORMAS TÉCNICAS. NBR 8633: carvão vegetal - determinação do poder calorífico. Rio de Janeiro, 1984. 13 p.

ABNT - ASSOCIAÇÃO BRASILEIRA DE NORMAS TÉCNICAS. NBR 6922: carvão vegetal - ensaios fisícos -determinação da massa específica do carvão vegetal. Rio de Janeiro, 1981. 1981. 2 p.

BRASIL - MINISTERIO DO MEIO AMBIENTE. Levantamento sobre a geração de resíduos provenientes da atividade madeireira e proposição de diretrizes para políticas, normas e condutas técnicas para promover o seu uso adequado. Curitiba: MMA, 2009.35 p.

BERGMAN, P.; BOERSMA, A.; KIEL, J.; PRINS, M. J.; PTASINSKI, K.; JANSSEN, F. J. Torrefaction for entrainedflow gasification of biomass. In: WORLD CONFERENCE AND TECHNOLOGY EXHIBITION ON BIOMASS FOR ENERGY, INDUSTRY AND CLIMATE PROTECTION. 2., Rome, 2005. Proceedings...Rome: ETA, 2005. p. $78-82$.

BERGMAN, P. C.; KIEL, J. H. Torrefaction for biomass upgrading. In: EUROPEAN BIOMASS CONFERENCE. 14., Paris, 2005. Proceedings... Denmark: EUBCE, 2005. p. 17-21.

BERGMAN, P. C.; VERINGA, H. J. Combined torrefaction and pelletisation. Utrecht: Senter Novem , 2005. 29 p.

BERGMAN, P.; BOERSMA, A.; KIEL, J.; PRINS, M. J.; PTASINSKI, K.; JANSSEN, F. J. Torrefaction for entrainedflow gasification of biomass. In: WORLD CONFERENCE AND TECHNOLOGY EXHIBITION ON BIOMASS FOR ENERGY, INDUSTRY AND CLIMATE PROTECTION. 2., Rome, 2005. Proceedings...Rome: ETA, 2005. p. $78-82$.

BRIDGEMAN, T. G.; JONES, J. M.; SHIELD, I.; WILLIAMS, P. T. Torrefaction of reed canary grass, wheat straw and willow to enhance solid fuel qualities and combustion properties. Fuel, v. 87, n. 6, p. 844-856, 2008.

BRIDGEMAN, T. G.; JONES, J. M.; WILLIAMS, A.; WALDRON, D. J. An investigation of the grindability of two torrefied energy crops. Fuel, v. 89, n. 12, p. 3911-3918, 2010.

CAVAGNOL, S.; ROESLER, J. F.; SANZ, E.; NASTOLL, W.; LU, P.; PERRÉ, P. Exothermicity in wood torrefaction and its impact on product mass yields: From micro to pilot scale. The Canadian Journal of Chemical Engineering, v. 93, n. 2, p. 331-339, 2015. 
CHEN, W. H.; KUO, P. C. Isothermal torrefaction kinetics of hemicellulose, cellulose, lignin and xylan using thermogravimetric analysis. Energy, v. 36, n. 11, p. 6451-6460, 2011.

CHEN, W.-H.; PENG, J.; BI, X. T. A state-of-the-art review of biomass torrefaction, densification and applications. Renewable and Sustainable Energy Reviews, v. 44, p. 847-866, 2015.

CHEN, W. H.; LU, K. M.; LIU, S. H.; TSAI, C. M.; LEE, W. J.; LIN, T. C. Biomass torrefaction characteristics in inert and oxidative atmospheres at various superficial velocities. Bioresource Technology, Essex, v. 146, p. 152-160, 2013.

CHEN, W. H.; CHENG, W. Y.; LU, K. M.; HUANG, Y. P. An evaluation on improvement of pulverized biomass property for solid fuel through torrefaction. Applied Energy, v. 88, n. 11, p. 3636-3644, 2011 a.

CHEN, W.; HSU, H.; LU, K.; LEE, W.; LIN, T. Thermal pretreatment of wood ( Lauan ) block by torrefaction and its in fl uence on the properties of the biomass. Energy, v. 36, n. 5, p. 3012-3021, 2011b.

CHEW, J. J.; DOSHI, V. Recent advances in biomass pretreatment - Torrefaction fundamentals and technology. Renewable and Sustainable Energy Reviews, v. 15, n. 8, p. 4212-4222, 2011c.

DEBAL, M.; GIRODS, P.; LÉMONON, J.; KARAMA, J. P.; DONNOT, A.; ROGAUME, Y. TG-FTIR kinetic study of the thermal cleaning of wood laminated flooring waste. Journal of Thermal Analysis and Calorimetry, v. 118, n. 1, p. 141-151, 2014.

ESTEVES, B.; GRAÇA, J.; PEREIRA, H. Extractive composition and summative chemical analysis of thermally treated eucalypt wood. Holzforschung, Berlin, v. 62, n. 3, p. 344-351, 2008.

GIRODS, P.; DUFOUR, A.; ROGAUME, Y.; ROGAUME, C.; ZOULALIAN, A. Pyrolysis of wood waste containing urea-formaldehyde and melamine-formaldehyde resins. Journal of Analytical and Applied Pyrolysis, v. 81, n. 1, p. 113-120, 2008.

GUCHO, E.; SHAHZAD, K.; BRAMER, E.; AKHTAR, N.; BREM, G. Experimental Study on Dry Torrefaction of Beech Wood and Miscanthus. Energies, v. 8, n. 5, p. 3903-3923, 2015.

JANKOWSKY, I. P.; GALINA, I. C. M. Secagem de madeiras. . São Paulo: Nobel , 2013

KHAZRAIE SHOULAIFAR, T.; DEMARTINI, N.; IVASKA, A.; FARDIM, P.; HUPA, M. Measuring the concentration of carboxylic acid groups in torrefied spruce wood. Bioresource Technology, v. 123, p. 338-343, 2012.

KROOK, J.; MÅRTENSSON, a.; EKLUND, M. Metal contamination in recovered waste wood used as energy source in Sweden. Resources, Conservation and Recycling, v. 41, n. 1, p. 1-14, 2004.

LEE, J. W.; KIM, Y. H.; LEE, S. M.; LEE, H. W. Optimizing the torrefaction of mixed softwood by response surface methodology for biomass upgrading to high energy density. Bioresource Technology, Essex, v. 116, p. 471-476, 2012.

NEUPANE, S.; ADHIKARI, S.; WANG, Z.; RAGAUSKAS, a. J.; PU, Y. Effect of torrefaction on biomass structure and hydrocarbon production from fast pyrolysis. Green Chemistry, London, v. 17, n. 4, p. 2406-2417, 2015.

PENTANANUNT, R.; RAHMAN, A. N. M. M.; BHATTACHARYA, S. C. Upgrading of biomass by means of torrefaction. Energy, v. 15, n. 12, p. 1175-1179, 1990.

PHANPHANICH, M.; MANI, S. Impact of torrefaction on the grindability and fuel characteristics of forest biomass. Bioresource Technology, Essex, v. 102, n. 2, p. 1246-1253, 2011. 
Andrade et al. - Changes caused by torrefaction on urban wooden waste

PIERRE, F.; ALMEIDA, G.; BRITO, J. O.; PERRÉ, P. Influence of torrefaction on some chemical and energy properties of maritime pine and pedunculate OAK. BioResources, v. 6, n. 2, p. 1204-1218, 2011.

PRINS, M. J.; PTASINSKI, K. J.; JANSSEN, F. J. J. G. Torrefaction of wood. Part 1. Weight loss kinetics. Journal of Analytical and Applied Pyrolysis, v. 77, n. 1, p. 28-34, 2006.

REPELLIN, V.; GOVIN, A.; ROLLAND, M.; GUYONNET, R. Modelling anhydrous weight loss of wood chips during torrefaction in a pilot kiln. Biomass and Bioenergy, Oxford, v. 34, n. 5, p. 602-609, 2010.

TAPPI - TECHNICAL ASSOCIATION OF PULP AND PAPER. TAPPI T-12 05-75 - Industry preparation of wood for chemical analysis (Including procedures for removal of extractives an determination of moisture content). Rapport, 1975.

TAPPI - TECHNICAL ASSOCIATION OF PULP AND PAPER. TAPPI 222 05-74 - Acid insoluble lignin in wood and pulp. Rapport, 1974.

VAN DER STELT, M. J. C.; GERHAUSER, H.; KIEL, J. H. a; PTASINSKI, K. J. Biomass upgrading by torrefaction for the production of biofuels: A review. Biomass and Bioenergy, Essex, v. 35, n. 9, p. 3748-3762, 2011.

VIGUIÉ, J.; ULLRICH, N.; POROT, P.; BOURNAY, L.; HECQUET, M.; ROUSSEAU, J. BioTfueL Project: Targeting the Development of Second-Generation Biodiesel and Biojet Fuels. v. 68, n. 5, 2013.

Recebido em 27/04/2016

Aceito para publicação em 09/01/2017 